\title{
PARTISIPASI MASYARAKAT DALAM MEREHABILITASI HUTAN MANGROVE DI DESA SUNGAI BAKAU BESAR LAUT KECAMATAN MEMPAWAH TIMUR KABUPATEN MEMPAWAH
}

\author{
(Community Participation in Rehabilitating Mangrove Forest in The Village Sungai Bakau \\ Besar Laut subdistrict Mempawah Timur Regency of Mempawah)
}

\author{
Ersyi Taruni, Sofyan Zainal, Burhanuddin \\ Fakultas Kehutanan Universitas Tanjungpura, Jalan Daya Nasional, Pontianak 78124 \\ E-mail: ersyitaruni89@gmail.com
}

\begin{abstract}
The condition of mangrove forests in the Sungai Bakau Besar Laut Village has been damaged, with these conditions it is necessary to participate from the surrounding community to carry out the rehabilitation of mangrove forests in order to repair the damage. For this reason, this study aims to explore the level of community participation in rehabilitating mangrove forests and Analyzing the relationship of community participation with age, education, knowledge and income towards participation in rehabilitating mangrove forests. The research method uses survey method with the sampling technique of respondents using purposive random sampling and interview techniques. Respondents in the study numbered 78 respondents. Indicators of success of community participation consists of several stages, namely the planning stage, the organizational stage, the implementation phase, and the evaluation stage. The results showed that community participation in planning and organizational activities was moderate, the level of community participation in implementation activities was low, and the level of participation in evaluation meetings was high. There is no relationship between age factors and income factors on community participation in rehabilitating mangroves, related to education factors on community participation are not related and there is a relationship between knowledge factors on community participation and very influential
\end{abstract}

Keywords: Community, Mangroves, Participation, Rehabilitation, Sungai Bakau

\section{PENDAHULUAN}

Sungai Bakau Besar Laut adalah daerah yang memiliki hutan mangrove yang telah mengalami kerusakan yang disebabkan karena penebangan pohon mangrove secara liar. Melihat kondisi mangrove yang rusak maka kondisi tersebut perlu diperbaiki dengan cara merehabilitasi hutan mangrove dan secara langsung melibatkan partisipasi dari masyarakat di Desa Sungai Bakau Besar Laut. Kegiatan rehabilitasi hutan mangrove dapat dilakukan dengan menanam mangrove jenis Rhizophora sp. pemilihan jenis ini selain ketersediaan bibit yang relatif mudah juga didasarkan pada kondisi substrat pasir berlumpur dan kemampuan tumbuh jenis ini sangat tinggi. Disarankan kepada pelaku rehabilitasi untuk menanam mangrove dari berbagai jenis sesuai dengan kesesuaian lahan untuk lokasi penanaman. (Fitri dan Iswahyudi, 2010)

Pada penelitian Setiawan (2016) mengatakan bahwa tingkat partisipasi masyarakat dalam merehabilitasi hutan mangrove di daerah pesisir pantai tergolong sedang, dikarenakan bahwa sebagian besar masyarakat telah memahami dan 
menyadari pentingnya upaya rehabilitasi hutan mangrove. Desa Sungai Bakau Besa Laut merupakan daerah pesisir dengan tingkat kerusakan mangrove cukup parah dan menjadi pusat perhatian dari berbagai pihak, hal tersebut dikarenakan aktifitas penebangan pohon mangrove tanpa adanya usaha untuk memperbaiki sehingga tidak terkontrol dan menyebabkan kerusakan di area mangrove tersebut dan memberikan dampak negatif bagi lingkungan khususnya di daerah pesisir pantai.

Berdasarkan uraian diatas, maka perlu dilakukan penelitian mengenai (1) Bagaimana tingkat partisipasi masyarakat dalam merehabilitasi hutan mangrove di Desa Sungai Bakau Besar Laut Kabupaten Mempawah. (2) Bagaimana Hubungan partisipasi masyarakat dengan umur, pendidikan, pengetahuan dan pendapatan terhadap partisipasi dalam merehabilitasi hutan mangrove. Penelitian ini bertujuan Untuk menjajaki tingkat partisipasi masyarakat dalam merehabilitasi hutan mangrove dan menganalisis hubungan partisipasi masyarakat dengan umur, pendidikan, pengetahuan dan pendapatan terhadap partisipasi dalam merehabilitasi hutan mangrove.

\section{METODE PENELITIAN}

Lokasi penelitian dilakukan di Desa Sungai Bakau Besar Laut Kecamatan Mempawah Timur Kabupaten Mempawah. Penelitian ini dilaksanakan mulai dari 19 Juli 2019 sampai dengan 19 Agustus 2019.

Alat yang digunakan dalam penelitian ini yaitu Kuisioner: serangkaian pertanyaan yang terlampir guna mendapatkan informasi yang diinginkan, alat tulis: untuk menulis hal-hal yang penting berkaitan dengan rehabilitasi hutan mangrove, peta lokasi, kamera: digunakan untuk mendokumentasikan kegiatan penelitian. Subjek penelitian ini adalah masyarakat di Desa Sungai Bakau Besar Laut Kecamatan Mempawah Timur Kabupaten Mempawah. Objek penelitian ini yaitu kawasan mangrove di Desa Sungai Bakau Besar Laut Kecamatan Mempawah Timur Kabupaten Mempawah.

Penelitian ini dilakukan dengan cara wawancara terhadap masyarakat langsung dan pengambilan sampel wawancara menggunakan teknik purposive random sampling yaitu pengambilan sampel yang menenkankan pada karakteristik tertentu dari objek penelitian (Subana dan Sudrajd, 2011). Jumlah KK yang tedapat di Desa Sungai Bakau Besar Laut yaitu sebanyak $1263 \mathrm{KK}$. Berdasarkan hasil perhitungan penentuan responden dengan rumus slovin sebagai berikut:

$$
n i=\frac{N i}{1+\Sigma N i \times \text { Eror }^{2}}
$$

Keterangan :

$\mathrm{n}=$ ukuran / jumlah sampel

$\mathrm{Ni}=$ ukuran / jumlah KK

$\mathrm{e}=$ batas kesalahan/ketidaktelitian (persen keloggaran 11\%)

Diketahui jumlah responden yang didapat dari $1263 \mathrm{KK}$ dari dua dusun yaitu Dusun Barat 951 KK dan Dusun Timur 312 KK dengan batas kesalahan 89\%. Maka dapat disimpulkan bahwa responden yang digunakan dalam penelitian ini sebanyak $78 \mathrm{KK}$.

Pengumpulan data pada penelitian ini yaitu dengan teknik wawancara dan observasi di lapangan. Data yang diperoleh terdiri dari data primer dan data sekunder. 
Data primer yaitu data yang diperoleh dari pengamatan langsung di lapangan. Sedangkan data sekunder adalah data yang diperoleh memlaui informasi dari instansi yang terkait di daerah tersebut.

Analisis yang digunakan dalam penelitian ini yaitu analisis deskriptif dan analisis iferensial. Analisis dekriptif dalam penelitian ini adalah mendeskripsikan hasil penelitian dari bentuk data ke dalam tulisan agar mudah di pahami dengan menggunakan tabulasi. Analisis inferensial merupakan analisis yang digunakan menggunakan uji statistik serta digunakan untuk menganalisis data sampel dengan bermaksud membuat kesimpulan yang berlaku umum atau generalisasi (Idrus, 2009) dengan menggunakan uji Korelasi Kendall Tau sebagai berikut:

$n=\frac{\Sigma A-\Sigma B}{\frac{N(N-1)}{2}}$

Dimana :

$r=$ Koefesien Korelasi Kendall Tau yang besarnya $(-1<0<1)$

$\mathrm{A}=$ Jumlah rangkaian atas

$\mathrm{B}=$ Jumlah rangkaian bawah

$\mathrm{N}=$ Jumlah gagasan sampel

Variabel penelitian dilakukan dengan pengkategorisasian yaitu Tingkat Umur (X1), untuk pengkategorian tingkat umur pada responden menurut (Rusli, 2012) usia produktif berada pada rentang 15-64 tahun. Umur yang berada pada usia produktif memberikan peluang yang potensial bagi pengelolaan hutan mangrove yang partisipatif. Tingkat Pendidikan (X2) dalam penelitian menggunakan kategori Tidak Tamat-Sekolah Dasar, Sekolah Menengah Pertama (SMP), Sekolah Menengah Atas (SMA), dan Perguruan
Tinggi (S1). Tingkat Pengetahuan (X3), pada tingkat pengetahuan partisipasi masyarakat dalam merehabilitasi hutan mangrove dapat di peroleh melalui perhitungan Skala Likert yaitu (skor 5-1) yakni tingkat persetujuan masyarakat terhadap rehabilitasi hutan mangrove di Desa Sungai Bakau Besar Laut, dengan jawaban sebagai berikut : a). sangat setuju, skor 5: b). setuju, skor (4): c). cukup setuju, skor (3): d). kurang setuju, skor (2): e). tidak setuju, skor (1). Selanjutnya partisipasi masyarakat di kategori kan dalam tiga kelompok, yaitu kategori tinggi, sedang, rendah, dengan menggunakan rumus Convidence Interval (Selang Kepercayaan) menurut Hasril Hitam (1980):

$\mathrm{CI}=\overline{\mathrm{Y}} \pm \mathrm{t} . \mathrm{Sx}$

Keterangan :

$\mathrm{CI}=$ Convidence Interval (selang Kepercayaan)

$\bar{Y}=$ Nilai Tengah (rata-rata X).

$\mathrm{t}=\mathrm{t}$ tabel $(89 \%)$.

$\mathrm{Sx}=$ Standar error

$S x=\sqrt{1-f\left(\frac{v r}{n}\right)}$

Dimana :

Sx : Standar Error

1 : Konstanta

f : Intensitas sampling $(0,06)$.

$\mathrm{Vr} \quad$ : Varians $\left(\mathrm{Sd}^{2}\right)$

N : Jumlah Sample.

Dengan ketentuan kategori sebagai berikut

Kategori Tinggi, jika CI $=\geq X+$ t. Sx

Kategori Sedang, jika CI $=\mathrm{X}-\mathrm{t}$. Sx s/d < $\mathrm{X}+\mathrm{t}, \mathrm{Sx}$

Kategori Netral, jika CI $=<\mathrm{X}-\mathrm{t}$.Sx

Sedangkan Tingkat Pendapatan (X4) menurut Entika Indrianawati (2015) kategori tingkat pendapatan meliputi 
golongan pendapatan sangat tinggi jika pendapatannya lebih dari Rp 3.500.000,per bulan, golongan pendapatan tinggi adalah jika pendapatan rata-rata antara $\mathrm{Rp}$. 2.500.000,- s/d Rp. 3.500.000,- per bulan, golongan pendapatan sedang berkisar antara Rp. 1.500.000,- s/d Rp. 2.500.000,per bulan, golongan pendapatan rendah yaitu sdibawah Rp. 1.500.000,-. Keempat kategori tersebut dihubungkan dengan variabel terikat (Y) yakni partisipasi masyarakat dalam merehabilitasi hutan mangrove. uji Korelasi Kendall Tau dengan bantuan komputer Program SPSS Versi 16.

\section{HASIL DAN PEMBAHASAN}

Karakteristik Responden Berdasarkan

\section{Tingkat Umur}

Karakteristik reponden berdasarkan tingkat umur tergolong atas kategori umur $\geq 40$ tahun berjumlah 20 responden, kategori umur 39-34 tahun berjumlah 26 responden, dan kategori umur $\leq 34$ tahun berjumlah 47 responden.

Tabel 1. Karakteristik Responden Berdasarkan Tingkat Umur (respondents Characteristics based on age level)

\begin{tabular}{|c|c|}
\hline Kategori umur & frekuensi \\
\hline$\geq 40$ & $21 \%$ \\
\hline $39-34$ & $28 \%$ \\
\hline$\leq 34$ & $51 \%$ \\
\hline jumlah & 100 \\
\hline $\begin{array}{l}\text { Responden yang mendominasi } \\
\text { adalah masyarakat yang berumur } \leq 34 \\
\text { tahun. Masyarakat yang mempunyai } \\
\text { umur } \leq 34 \text { tahun yaitu masyarakat yang } \\
\text { masih muda atau dapat dikatakan masih } \\
\text { banyak kesempatan untuk mengikuti } \\
\text { semua kegiatan rehabilitasi yang di } \\
\text { lakukan. Masyarakat yang berumur } \\
\text { Antara 39-34 tahun adalah masyarakat } \\
\text { yang dapat dikatakan sudah sangat } \\
\text { dewasa atau berada pada usia produktif, } \\
\text { sehingga memiliki pemikiran yang baik }\end{array}$ & $\begin{array}{l}\text { lebih besar kemungkinan berhasilnya } \\
\text { pada usia produktif (Tambunan, } \\
\text { Harahap, dan Lubis 2005). Sedangkan } \\
\text { responden dengan umur } \geq 40 \text { tahun ialah } \\
\text { responden yang kurang aktif untuk } \\
\text { berkontribusi dengan kegiatan yang } \\
\text { dilakukan oleh pihak Desa, mereka lebih } \\
\text { memilih bekerja bertani dan berkebun } \\
\text { sebagian kecil masyarakat yang } \\
\text { berkontribusi adalah masyarakat yang } \\
\text { yang masih merasa mampu untuk } \\
\text { mengikuti kegiatan tersebut. }\end{array}$ \\
\hline
\end{tabular}
untuk lingkungan dan bisa menjadi contoh bagi generasi dibawahnya untuk selalu menjaga lingkungan dan selalu melestarikan lingkungan terutama kawasan hutan mangrove. Umur yang berada di usia produktif memberikan peluang yang potensial bagi pengelolaan hutan mangrove yang partisipastif. Hal ini didasari atas kemampuan menyerap dan melakukan kegiatan partisipatid

\section{Karakteristik Responden}

Berdasarkan Tingkat Pendidikan

Pendidikan responden sangat beragam, mulai dari tidak sekolah, Sekolah Dasar (SD), Sekolah Menengah Pertama (SMP), Sekolah Menengah Atas (SMA), hingga Perguruan Tinggi. Keragaman tingkat pendidikan Responden dapat dilihat pada Tabel 2. 
Tabel 2. Karakteristik Responden Berdasarkan Tingkat Pendidikan (respondents Characteristics based on education level)

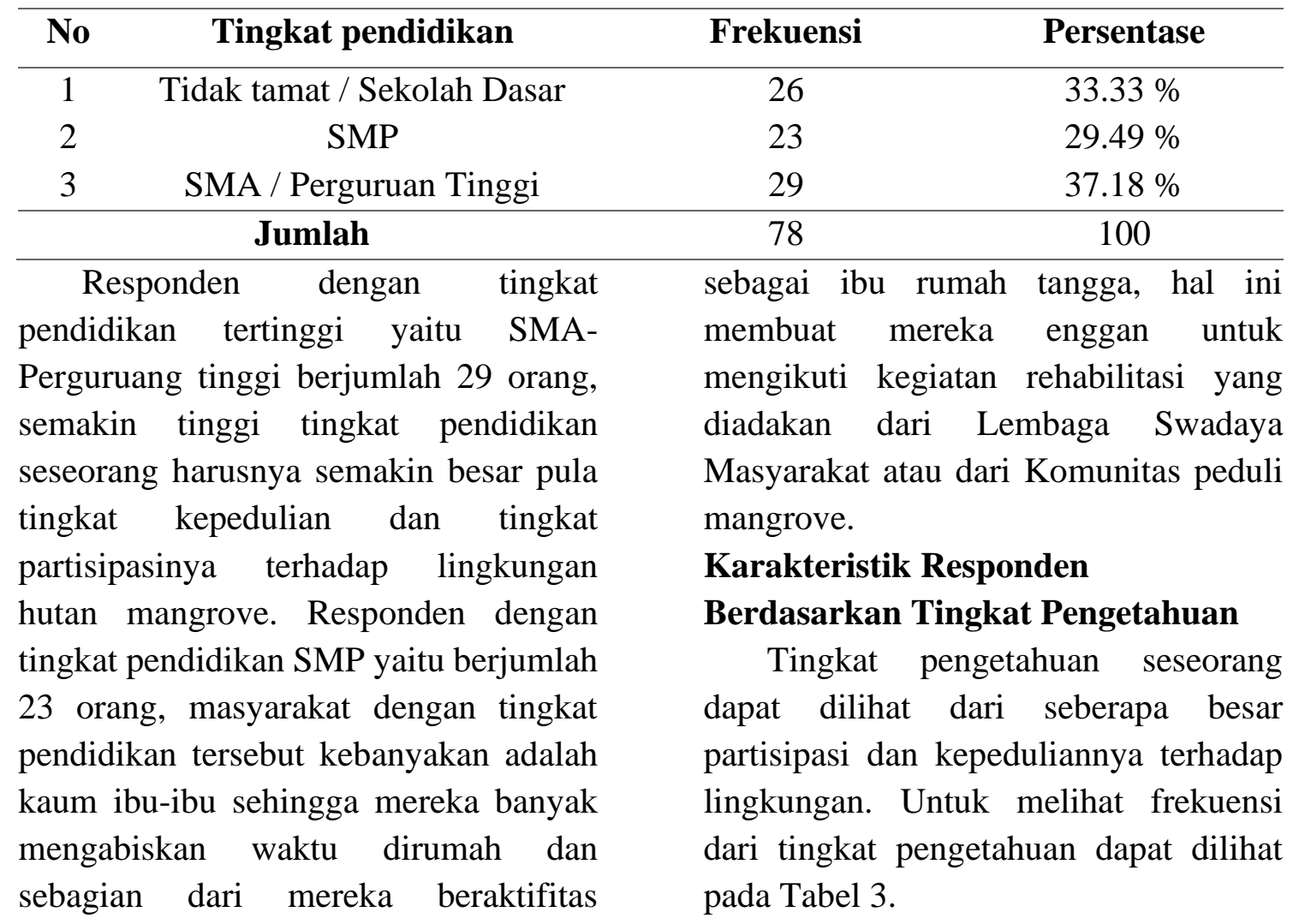

Tabel 3. Karakteristik Responden Berdasarkan Tingkat Pengetahuan (respondents Characteristics based on knowledge level)

\begin{tabular}{|c|c|}
\hline Pengetahuan & Persentase \\
\hline Tinggi & $51.28 \%$ \\
\hline Sedang & $2.56 \%$ \\
\hline Rendah & $46.15 \%$ \\
\hline Jumlah & 100 \\
\hline Masyarakat di Desa Sungai Bakau & masyarakat \\
\hline $\begin{array}{l}\text { Besar Laut memiliki pengetahuan yang } \\
\text { sangat tinggi tentang hutan mangrove } \\
\text { dengan frekuensi } 51,28 \% \text {, masing- } \\
\text { masing masyarakat sangat memahami } \\
\text { manfaat dan pentingnya keberadaan } \\
\text { hutan mangrove di pesisir pantai. Tetapi } \\
\text { dengan tingkat pengetahuan yang tinggi } \\
\text { tidak menjamin besarnya partsipasi }\end{array}$ & $\begin{array}{l}\text { keberadaan hutan mangrove tetapi } \\
\text { belum sempurna memahami betapa } \\
\text { petingnya hutan mangrove tersebut. } \\
\text { Masyarakat dengan pengetahuan rendah } \\
\text { adalah masyarakat yang sama sekali } \\
\text { tidak mengetahui pentingnya keberadaan } \\
\text { hutan mangrove dan tidak memahami } \\
\text { bahwa kegiatan rehabilitasi merupakan }\end{array}$ \\
\hline $\begin{array}{l}\text { masyarakat. Tingkat pengetahuan } \\
\text { mansyarakat tegolong sedang adalah }\end{array}$ & kegiatan yang sangat penting untuk \\
\hline
\end{tabular}


dilakukan pada area mangrove yang rusak.

\section{Karakteristik Responden}

\section{Berdasarkan Tingkat Pendapatan}

Faktor pendapatan berkaitan dengan mata pencaharian seserorang. Masyarakat di Desa Sungai Bakau Besar Laut didominasi oleh petani dan nelayan. Masyarakat yang harusnya lebih aktif dalam kegiatan rehabilitasi hutan mangrove adalah nelayan karena pelestarian hutan mangrove dapat menambah nilai ekonomi dari hasil tangkapan nelayan tersebut. Berdasarkan hasil penelitian dari 78 responden maka dapat diketahui frekuensi tingkat pendapatan dari masyarakat yang di kelompokkan mulai dari $\geq 1.380 .000$, 1.380.000 - 1.031.000, dan $\leq 1.031 .000$. Dalam penelitian bahagia (2008) semakin tinggi tingkat penghasilan, semakin besar kemungkinan partisipasi dalam merehabilitasi hutan mangrove. Frekuensi pendapatan responden dapat dilihat pada Tabel 4 .

Tabel 4. Karakteristik Responden Berdasarkan Tingkat Pendapatan (respondents Characteristics based on income level)

\begin{tabular}{cccc}
\hline No & Pendapatan & Frekuensi & Persentase \\
\hline 1 & $\geq 1.380 .000$ & 27 & $34.62 \%$ \\
2 & $1.380 .000-1.031 .000$ & 6 & $7.69 \%$ \\
3 & $\leq 1.031 .000$ & 45 & $57.69 \%$ \\
\hline & Jumlah & 78 & 100 \\
\hline
\end{tabular}

Masyarakat yang berpenghasilan $\geq$ 1.380.000 adalah sebagian bekerja sebagai nelayan atau bos ikan ada juga mereka yang bekerja di perusahaan lain di luar daerah mereka. Masyarakat yang berpenghasilan $1.380 .000-1.031 .000$ adalah mereka yang bekerja sebagai guru dan sebagai nelayan biasa. Sedangkan masyarakat yang berpenghasilan $\leq$
1.031.000 adalah masyarakat yang bekerja sebagai buruh tani atau buruh nelayan dan sebagian bekerja sebagai pedagang kecil-kecilan.

\section{Partisipasi Masyarakat Dalam Merehabilitasi Hutan Mangrove}

Tingkat partisipasi masyarakat dalam merehabilitasi hutan mangrove dapat dilihat pada tabel berikut

Tabel 5. Tingkat Partisipasi Pada Kegiatan Rehabiliitasi (Level of Participation at the Participation stage)

\begin{tabular}{|c|c|c|c|c|c|c|c|c|c|}
\hline \multirow{3}{*}{ No } & \multirow{3}{*}{$\begin{array}{c}\text { Kategori } \\
\text { Tingkat } \\
\text { Partisipasi }\end{array}$} & \multicolumn{8}{|c|}{ Tingkat Partisipasi Pada Tahap Partisipasi } \\
\hline & & \multicolumn{2}{|c|}{ Perencanaan } & \multicolumn{2}{|c|}{ Organoisasi } & \multicolumn{2}{|c|}{ Pelaksaanaan } & \multicolumn{2}{|c|}{ Evaluasi } \\
\hline & & $\mathbf{F}$ & $\%$ & $\mathbf{F}$ & $\%$ & $\mathbf{F}$ & $\%$ & $\mathbf{F}$ & $\%$ \\
\hline 1 & Tinggi & 15 & 19.23 & 20 & 25.64 & 31 & 39.74 & 30 & 38.46 \\
\hline 2 & Sedang & 33 & 42.31 & 31 & 39.74 & 7 & 8.97 & 29 & 37.18 \\
\hline 3 & Rendah & 30 & 38.46 & 27 & 34.62 & 40 & 51.28 & 19 & 24.36 \\
\hline \multicolumn{2}{|c|}{ Total } & 78 & 100 & 78 & 100 & 78 & 100 & 78 & 100 \\
\hline \multicolumn{2}{|c|}{ Partisipasi } & nasy & kat & & \multicolumn{5}{|c|}{ memiliki nilai persentase sebesar 51,28} \\
\hline
\end{tabular}


pelaksanaan kegiatan rehabilitasi hutan mangrove masyarakat tidak mengikuti kegiatan yang diadakan disebabkan oleh masyarakat sibuk dengan pekerjaan utamanya sehingga masyarakat tidak ikut dalam pelaksanaan rehabilitasi hutan mangrove. Kebanyakan dari masyarakat juga tidak terlalu memperdulikan karena alasan mereka kegiatan tersebut sudah ada yang menanganinya sehingga mereka tidak perlu ikut untuk berpartisipasi.

Pada tahap perencanaan partisipasi masyarakat tergolong sedang hal ini disebabkan oleh masyarakat yang ikut dalam kegiatan perencanaan hanyalah masyarakat yang berperan aktif dalam pembangunan Desa, masyarakat lainnya tidak diikut sertakan dalam tahap perencanaaan. Partisipasi masyarakat pada tahap organisasi tergolong sedang disebabkan oleh orang-orangyang tergabung dalam organisasi ini adalah dari instansi Desa dan beberapa masyarakat sekitar yang ikut berperan dalam kegaiatan pembangunan Desa. Pada tahap evaluasi partisipasi masyarakat dikategorikan tinggi karena pada tahap evaluasi ini setiap masyarakat yang merasa dirinya berperan dalam kegiatan rehabilitasi ikut dalam kegiatan evaluasi. Dalam kegiatan evaluasi masyarakat yang hadir sebagian besar hanya menyampaikan ide-ide agar hutan mangrove di daerah tersebut menjadi daya tarik bagi masyarakat sekitar dan masyarakat luar. Tahap evalusi ini dapat dilihat dari segi pemeliharaan, pelestarian dan pengawasan. Menurut Erwiantono (2006) untuk mengetahui berhasil atau tidaknya suatu partisipasi masyarakat dapat diketahui dari beberapa indicator yang dinilai mulai dari perencanaan, pelaksanaan, evaluasi dan menikmati hasil.

\section{Hubungan Variabel Terikat dengan variabel Bebas}

Untuk mengetahui hubungan antara variabel terikat (tingkat partisipasi) dengan variabel bebas (umur, pendidikan, pengetahuan, dan pendapatan) dapat dilakukan dengan uji korelasi Kendall tau. Hasil dari uji korelasi Kendal Tau dapat dilihat pada tabel 6 .

Tabel 6. Hubungan karakterisitik variabel bebas dan variabel terikat (Contact Between the independent Variables and dependent variables

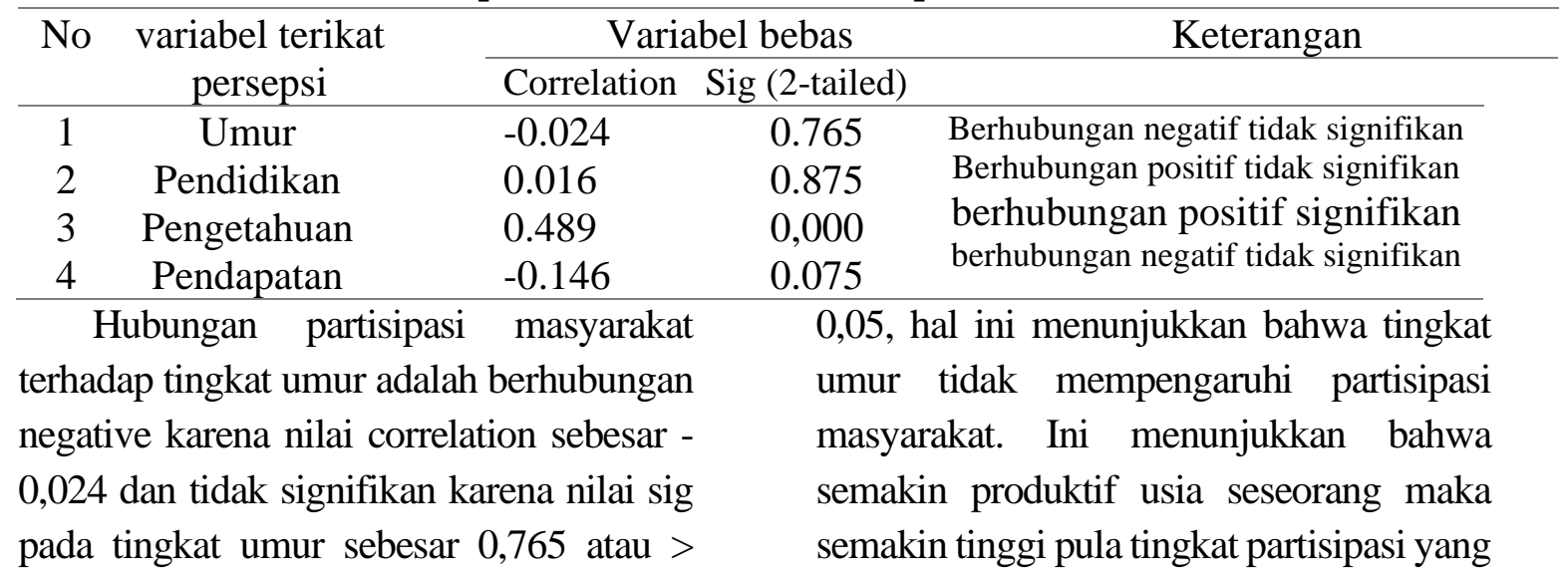


diberikan (Tambunan, Harahap, dan Lubis 2005). Tetapi fakta dilapangan menunjukkan bahwa dalam berpartisipasi umur muda ataupun tua jika masyarakat merasa peduli terhadap lingkungan mereka akan tetap berpartisipasi dan ikut dalam semua kegiatan rehabilitasi yang di adakan.

Pada tingkat pendidikan memiliki nilai correlation sebesar 0,016 yang berarti berhubungan positif tetapi tidak signifikan karena memiliki nilai sig sebesar 0,875 atau $>0,05$, artinya tingkat pendidikan sangatlah mempengaruhi pola pikir pada setiap individu, semakin tinggi tingkat pendidikan seseorang maka semakin bisa ia berpikir bahwa setiap kegiatan rehabilitasi merupakan kegiatan yang sangat baik untuk lingkungan, hal tersebut seharusnya dapat mendorong masyarakat untuk ikut dalam berpartisipasi, tetapi fakta dilapangan menunjukkan bahwa tingkat pendidikan seseorang yang tinggi tidak menjamin bahwa ia akan berpartisipasi karena mereka lebih memilih melakukan kegiatan lain yang sesuai dengan tingkat pendidikannya, sedangkan masyarakat yang berpendidikan Sekolah Dasar atau tidak tamat, mereka kebanyakan adalah yang tidak tahu akan pentingnya keberadaan hutang mangrove tetapi sebagian dari mereka juga ada yang mengetahui bahwa kegiatan rehabilitasi mangrove merupakan kegiatan yang sangat penting bagi daerahnya. Dalam penelitian Yosafat (2016) menunjukkan bahwa hubungan tingkat pendidikan dengan tingkat partisipasi masyarakat sangat lemah karena pendidikan responden hanya pada tingkat SD ataupu tidak tamat tetapi tingkat pendidikan tidak menjadi penghalang bagi mereka yang ingin berpartisipasi dalam kegaiatan rehabilitasi hutan mangrove.

Pada tingkat pengetahuan memiliki nilai correlation sebesar 0,489 yang berarti berhubungan positif dan signifikan karena memiliki nilai sig sebsesar 0,000 atau tidak $>0,05$, pada tahap pengetahuan sangatlah berpengaruh terhadap sikap seseorang untuk mengikuti setiap kegiatan yang dilakukan. semakin luas pengetahuan seseorang terhadap rehabilitasi hutan mangrove maka semakin banyak pula masyarakat harusnya mengikuti kegiatan rehabilitasi hutan mangrove. Sedangkan pada tingkat pendpatan memiliki nilai correlation sebesar -0,146 yang berarti berhubungan negative dan memiliki nilai sig sebesar 0,075 atau tidak signifikan karena nilai sig > 0,05, pada tingkat pendapatan tidak berhubungan dengan tingkat partisipasi, karena masyarakat lebih terfokus dengan pekerjaan utamanya.

\section{Hubungan Partisipasi Masyarakat Dalam Merehabilitasi Hutan Mangrove dengan Tingkat Umur}

Hubungan tingkat umur dengan tingkat partisipasi masyarakat dilakukan dengan Uji Korelasi Kendal Tau yang diolah dengan menggunakan program SPSS 16. Hasil penelitian menunjukkan bahwa tingkat umur dari 78 responden dikategorikan dalam 3 rentang yaitu rentang umur $\geq 40$ tahun, 39-34 tahun, dan $\leq 34$ tahun. Responden dengan umur $\geq 40$ tahun berjumlah 20 orang dengan persentase $21 \%$, masyarakat yang berumur $\geq 40$ sangat rendah dalam berpartisipasi dikarenakan sudah tidak mampu lagi untuk mengikuti kegiatan-kegiatan dilapangan, mereka kebanyakan hanya dirumah saja, kalaupun ada masyarakat yang 
berpartisipasi pada rentang umur $\geq 40$ tahun adalah mereka yang masih mempunyai tenaga yang cukup untuk bekerja dilapangan dan mengikuti kegiatan rehabilitasi.

Responden dengan umur 39-34 tahun berjumlah 26 responden dengan persentase $28 \%$. Masyarakat yang memiliki umur antara 39-34 tahun tingkat partisipasinya cukup dikatakan rendah karena masyarakat dengan rentang umur 39-34 lebih banyak mementingkan pekerjaan utamanya dibanding mengikuti kegiatan rehabilitasi hutan mangrove. Sedangkan rentang umur $\leq 34$ tahun berjumlah 47 responden dengan persentase $51 \%$ adalah umur responden yang sangat dominan. Secara umum biasanya masyarakat pada rentang umur $\leq$ 34 tahun adalah masyarakat yang sangat aktif dalam berbagai kegiatan, termasuk kegiatan rehabilitasi hutan mangrove tersebut. Tetapi hasil penelitian menunjukkan masyarakat yang berada pada tingkat umut $\leq 34$ tahun lebih banyak menghabiskan waktu bekerja diluar daerah mereka sehingga untuk mengikuti kegiatan rehabilitasi itu sangat sulit. Adapun mereka yang tinggal dirumah kebanyakan adalah ibu rumah tangga sehingga tidak memiliki waktu untuk mengikuti kegiatan rehabilitasi. Menurut (Rusli, 2012) usia produktif berada pada rentang 15-64 tahun. Umur yang berada pada usia produktif memberikan peluang yang potensial bagi pengelolaan hutan mangrove yang partisipatif. Hal ini didasari atas kemampuan menyerap dan melakukan kegiatan partisipatif lebih besar kemungkinan berhaasilnya pada usia produktif (Tambunan, et., al 2005).
Hubungan tingkat umur dengan partisipasi masyarakat dalam merehabilitasi hutan mangrove adalah berhubungan negative tidak signifikan karena memiliki nilai correlation sebesar 0.024 dengan nilai Sig (2-tailled) sebesar 0.765 hal ini dapat diartikan bahwa semakin tinggi tingkat umur semakin rendah partisipasinya dalam kegiatan rehabilitasi hutan mangrove dan kedewasaan seseorang untuk berpartisipasi tidak tergantung umur yang dijalaninya. Dalam penelitian Yosafat (2016) mengatakan bahwa tingkat umur dengan tingkat partisipasi tidak terdapat korelasi yang signifikan ini artinya hubungan antara umur dengan tingkat partisipasi sangat lemah.

\section{Hubungan Partisipasi Masyarakat Dalam Merehabilitasi Hutan Mangrove dengan Tingkat Pendidikan}

Berdasarkan hasil penelitian bahwa pendidikan masyarakat di Desa Sungai Bakau Besar Laut mulai dari Tidak Tamat/Sekolah Dasar berjumlah 26 orang dengan frekuensi 33,33\%, sedangkan untuk tingkat jenjang pendidikan Sekolah Menengah Pertama (SMP) dari 78 masyarakat yang dijadikan responden adalah berjumlah 23 orang dengan persentase 29,49\%, kemudian untuk tingkat pendidikan jenjang Sekolah Menengah Atas (SMA) hingga Perguruan Tinggi berjumlah 29 orang atau 37,18\%. Tingkat pendidikan yang baik akan mempengaruhi partisipasi masyarakat terhadap pengelolaan kawasan hutan mangrove yang di tunjukkan dengan tingginya keinginan masyarakat untuk menjaga dan melestarikan (Diarto, Hendarto, dan Suryoko 2012). Kenyataan 
dilapangan menunjukkan masyarakat tidak maksimal dalam berpartisipasi untuk merehabilitasi hutan mangrove. Pendidikan responden yang mendominasi adalah tingkat pendidikan SMA hingga perguruan tinggi. Pada tingkat pendidikan SMA/Perguruan Tinggi harusnya partisipasi masyarakat sangatlah baik karena semakin tinggi pendidikan seseorang maka semakin banyak pengetahuan yang mereka peroleh, termasuk pentingnya rehabilitasi hutan mangrove bagi lingkungan sekitar pantai. Tetapi fakta di lapangan, semakin tinggi pendidikan seseorang, tingkat partisipasi masyarakat tidak lah maksimal, karena kebanyakan masyarakat yang memiliki pendidikan yang tinggi lebih mementingkan pekerjaan utamanya seperti menjadi Guru, atau berdagang.

Hubungan tingkat pendidikan dengan tingkat partisipasi masyarakat memiliki nilai correlation 0.016 dan nilai Sig 0.875 Yang berarti pendidikan berhubungan positif tetapi tidak signifikan karena tingkat pendidikan memiliki nilai Sig $>0,05$. Hal ini dapat dikatakan bahwa setiap pendidikan seseorang dapat menunjang keaktifannya dalam berpartisipasi karena semakin tinggi tingkat pendidikan seseorang semakin banyak pengetahuan yang di ketahui oleh masyarakat iu sendiri dan partisipasinya semkain baik. Pangestu (1995) menyatakan bahwa tingkat pendidikan seseorang akan mempengaruhi tingkat partisipasi dalam suatu kegiatan. Fakta dilapangan menunjukkan bahwa tingkat pendidikan masyarakat yang tinggi tidak membuatnya tertarik untuk mengikuti kegiatan karena mereka lebih memilh mencari kesibukan yang sesuai dengan pendidikan yang di laluinya.

\section{Hubungan Partisipasi Masyarakat Dalam Merehabilitasi Hutan Mangrove dengan Tingkat Pengetahuan}

Berdasarkan hasil penelitian dari 78 responden, maka dapat diketahui bahwa tingkat pengetahuan masyarakat dikategorikan dalam 3 (Tiga) kategori, yaitu tinggi, sedang, rendah. Hasil uji statistik ( uji korelasi Kendal Tau) diketahui pengetahuan memiliki nilai sig (2-tailled) memiliki nilai sebesar 0,000 dan nilai correlation sebesar 0,489 yang berarti tingkat pengetahuan berhubungan positif signifikan. sehingga dapat disimpulkan bahwa terdapat hubungan antara pengetahuan dengan tingkat partisipasi masyarakat dalam merehabilitasi hutan mangrove di Desa Sungai Bakau Besar Laut Kecamatan Mempawah Timur Kabupaten Mempawah. Tingkat pengetahuan masyarakat cenderung lebih tinggi dengan jumlah prsentase sebesar $51,28 \%$ hal ini berarti semakin tinggi tingkat pengetahuan masyarakat terhadap fungsi rehabilitasi hutan mangrove semakin banyak masyarakat yang harusnya mengikuti kegiatan rehabilitasi mangrove di Desa Sungai Bakau Besar Laut tersebut. Pada tingkat pengetahuan tinggi dapat diartikan bahwa masyarakat dengan tingkat pengetahuan yang tinggi adalah masyarakat yang sangat memahami betapa penting nya keberadaan hutan mangrove di pesisir pantai, memahami bahwa fungsi hutan mangrove sangatlah penting untuk lingkungan dan masyarakat dengan tingkat pengetahuan tinggi ini sangat memahami bahwa kegiatan rehabilitasi hutan 
mangrove sangatlah penting untuk dilakukan pada area mangrove yang rusak.

Pada tingkat pengetahuan sedang sebanyak 2 responden dengan persentase sebesar $2.56 \%$, tingkat pengetahuan sedang dapat diartikan bahwa masyarakat pada tahap ini memiliki pemahaman yang tidak begitu tinggi dan juga rendah, dalam kata lain tingkat pengetahuan masyarakat tidak terlalu banyak mengenai fungsi dan pentingnya keberadaan hutan mangrove. Sedangkan pada tingkat pengetahuan rendah memiliki nilai frekuensi 36 responden dengan persentase sebesar 46.15 $\%$. Masyarakat yang tergolong dalam tingkat pengetahuan rendah yaitu masyarakat yang memiliki sedikit pengetahuan tentang pentingnya keberadaan hutang mangrove, hal ini dapat dipicu oleh tingkat pendidikan dan tingkat umur pada responden. Sebagaimana yang dijelaskan oleh Hemi (2017) dalam penelitiannya mengatakan bahwa ada pengaruh yang signifikan antara pengetahuan dan sikap terhadap partisipasi penduduk dengan program rehabilitasi mangrove,

\section{Hubungan Partisipasi Masyarakat Dalam Merehabilitasi Hutan Mangrove dengan Tingkat Pendapatan}

Hasil penelitian menunjukkan bahwa tingkat pendapatan masyarakat mulai dari $\geq$ Rp. 1.380.000,- yang berjumlah 27 responden dengan persentase 34,62 \%, kemudian pendapatan Rp. 1.380.000,hingga Rp. 1.030.000,- yang berjumlah 6 orang dengan persentase 7,69\%, kemudian responden yang berpendapatan Rp. $\leq$ 1.031.000,- berjumlah 45 responden dengan persentase sebesar 57,69\%. Hasil penelitian menunjukkan bahwa tingkat pendapatan masyarakat mulai dari $\geq \mathrm{Rp}$. 1.380.000,- yang berjumlah 27 responden dengan persentase 34,62 \%, kemudian pendapatan Rp. 1.380.000,- hingga Rp. 1.030.000,- yang berjumlah 6 orang dengan persentase 7,69\%, kemudian responden yang berpendapatan Rp. $\leq 1.031 .000,-$ berjumlah 45 responden dengan persentase sebesar 57,69\%. Dapat dilihat pada tabel berikut :

Tabel 7. Karakteristik Responden Berdasarkan Tingkat Pendapatan Pendidikan (Repondent Characteristics Based on Income Level)

\begin{tabular}{cccc}
\hline No & Pendapatan & Frekuensi & Persentase \\
\hline 1 & $\geq 1.380 .000$ & 27 & $34.62 \%$ \\
2 & $1.380 .000-1.031 .000$ & 6 & $7.69 \%$ \\
3 & $\leq 1.031 .000$ & 45 & $57.69 \%$ \\
\hline & Jumlah & 78 & 100 \\
\hline
\end{tabular}

Faktor pendapatan berkaitan dengan mata pencaharian seseorang. Masyarakat di Desa Sungai Bakau Besar Laut sebagian besar mata pencahariannya adalah petani dan nelayan yang pendapatannya bersifat tidak tetap dan tergantung dari hasil penangkapan dan pertanian. Dilihat dari profesi masyarakat Desa Sungai Bakau Besar Laut yang kebanyakan nelayan dan petani, sebaga nelayan harusnya lebih paham pentingnya keberadaan hutan mangrove di pesisir pantai karena dapat menambah hasil tangkapan ikan, dan 
menambah pendapatan masyarakat itu sendiri. Disisi lain masyarakat yang berprofesi sebagai petani lebih bisa memanfaatkan hasil hutan mangrove itu sendiri, memanfaatkan buah mangrove sebagai olahan, memnafaatkan kayu sebagai bahan bakar, dan manfaatmanfaat lainnya yang dapat di ambil dari hutan mangrove tersebut. Masyarakat di Desa Sungai Bakau Besar Laut sudah ada yang memanfaatkan buah mangrove yang diolah menjadi sirup dan dodol. Hal tersebut dapat meningkatkan pendapatan masyarakat di Desa Sungai Bakau Besar Laut.

Hubungan tingkat pendapatan dengan partisipasi masyarakat dalam merehabilitasi hutan mangrove yaitu dapat dilihat pada Tabel 7 bahwa tingkat pendapatan berhubungan negatif tidak signifikan karena memiliki nilai correlation sebesar -0,146 dan memiliki nilai sig sebesar 0,075 atau $>0,05$. Hal ini dapat disimpulkan bahwa pendapatan tidak memiliki hubungan terhadap tingkat partisipasi masyarakat dalam merehabilitasi hutan mangrove di Desa Sungai Bakau Besar Laut. Hal ini berbanding terbalik dengan penelitian Pangestu (1995) yang mengatakan bahwa tingkat pendapatan merupakan faktor yang dapat mempengaruhi pasrtisipasi. Dalam penelitian bahagia (2008) semakin tinggi tingkat penghasilan, semakin besar kemungkinan partisipasi dalam merehabilitasi hutan mangrove. Masyarakat Desa Sungai bakau Besar Laut memiliki pekerjaan utama dan pekerjaan sampingan. Sehingga masyarakat lebih terfokus dengan pekerjaan yang dimiliki nya. Masyarakat ikut berpartisipasi dalam merehabilitasi hutan mangrove ketika mempunyai waktu diluar waktu pekerjaan utamanya hal ini membuktikan bahwa pendapatan masyarakat tidak ada pengaruh terhadap kegiatan rehabilitasi hutan mangrove.

\section{KESIMPULAN}

Hasil penelitian menunjukkan bahwa tingkat partisipasi masyarakat pada tahap perencanaan dan tahap organisasi tergolong sedang, tingkat partisipasi masyarakat dalam tahap pelaksanaan tergolong rendah, dan tingkat partisipasi pada tahap evaluasi tergolong tinggi. Tidak adanya hubungan antara faktor umur dan faktor pendapatan terhadap tingkat partisipasi masyarakat dalam merehabilitasi hutan mangrove, terdapat hubungan antara faktor pendidikan terhadap partisipasi masyarakat tetapi tidak berpengaruh dan adanya hubungan antara faktor pengetahuan terhadap partisipasi masyarakat dan sangat berpengaruh

\section{SARAN}

Diharapkan kepada instansi terkait di Desa Sungai Bakau Besar Laut lebih aktif dalam mengajak masyarakatnya untuk selalu ikut dalam kegiatan pelaksanaan, sehingga masyarakat lebih peduli terhadap lingkungannya dan perangkat Desa yang berpengaruh di Desa Sungai Bakau Besar Laut bersikap terbuka terhadap masyarakatnya agar masyarakat tiak sungkan jika diadakan kegiatan-kegiatan rehabilitasi tersebut dan perlunya kesadaran dari masyarakat sekitar untuk lebih aktif mengikuti 
kegiatan rehabilitasi sehingga menumbuhkan kepedulian masyarakat terhadap lingkungan dan perlunya meningkatkan kerjasama antar masyarakat agar dapat mencapai keberhasilan dalam kegiatan rehabilitasi hutan mangrove.

\section{DAFTAR PUSTAKA}

Bahagia. 2008. Peran Pemenrintah Daerah dan Partisipasi Masyarakat dalam Rehabilitasi Hutan Mangrove Pasca Tsunami Di kecamatan Baitussalam Tahun 2008.

Diarto, Hendrarto B, Suryoko S. 2012. Partisipasi Masyarakat Dalam Pengelolaan Lingkungan Kawasan Hutan Mangrove Tugurejo di Kota Semarang. Jurnal Ilmu Lingkungan.

Erwiantono. (2005). Kajian Tingkat Partisipasi Masyarakat Dlam Pengelolaan Ekosistem mangrove di Kawasan Teluk Psngpsng Banyuwangi. Universitas Brawijaya malang

Fitri, R dan Iswahyudi. 2010. Evaluasi Karakterisitik Lahan Hutan Mangrove di Kabupaten Aceh Timur. Jurnal Hidrlotan.

Hasril, H. 1980. Dasar-Dasar Teori Penggunaan Tekik Pengambilan Contoh (Sampling Techniques) dakam Inventarisasi Hutan. Jakarta. Pradnya Paramita.

Idrus, Muhammad. 2009. Metode Penelitian Ilmu Sosial, Pendekatan Kualitatif dan Kuantitatif. Jakarta: Erlangga
Indrianawati, Entika. 2015. Pengaruh Tingkat Pendapatan dan Pengetahuan Ekonomi Terhadap Tingkat Konsumsi Mahasiswa Program Pasca Sarjana Universitas Negeri Surabaya. Universitas Negeri Surabaya

Rusli, S. 2012. Pengantar Ilmu Kependudukan. Jakarta (ID): LP3ES

Subana dan Sudrajat. 2011. DasarDasar Penelitian Ilmiah. Bandung: Pustaka Setia

Tambunan R, Harahap RH, Lubis Z. 2005. Pengelolaan Hutan Mangrove Di Kabupaten Asahan (Studi Kasus Partisipasi Masyarakat dalam Pengelolaan Hutan Mangrove di Kecamatan Lima Puluh Kabupaten Asahan). Jurnal Studi Pembangunan

Pangestu MHT. 1995. Partisipasi Masyarakat Dalam Pelaksanaan Kegiatan Perhutanan Sosial (Studi Kasus: KPH Cianjur Jawa Barat). Tesis Pascasarjana. Institut Pertanian Bogor. Bogor.

Martunas Manalu, Yosafat. 2016. Hubungan Tingkat Partisipasi Masyarakat Dalam Pengelolaan Ekosistem Mangrove Di Desa Ujungalang. Institut Pertanian Bogor. Bogor

Wulan Martatiwi, Hemi. 2017. Pengaruh Pengetahuan dan Sikap Terhadap Partispasi Penduduk Dalam Pemanfaatan Program Rehabilitasi Mangrove. Universitas Negeri Semarang 